\begin{tabular}{l|l} 
Mekanika: majalah ilmiah mekanika & 44
\end{tabular} Volume 17 Nomor 2 September 2018

\title{
KARAKTERISASI BIOKOMPOSIT SHEEP HYDROXYAPATITE (SHA)/SHELLAC/TEPUNG TERIGU
}

\author{
Izmi Mahfudi ${ }^{1}$, Joko Triyono ${ }^{1}$, Teguh Triyono $^{1}$ \\ ${ }^{1}$ Teknik Mesin - Universitas Sebelas Maret \\ e-mail address : ismimahfudi@yahoo.com
}

\begin{tabular}{|c|c|}
\hline Keywords: & Abstract: \\
\hline $\begin{array}{l}\text { Sheep hydroxyapatite, XRD, SEM, } \\
\text { Hardness Number (VHN) }\end{array}$ & $\begin{array}{l}\text { The development of science and technology has led to new } \\
\text { inovations in the medical field, especially ortopedic. The aim of those } \\
\text { inovations is to find the alternatives of good materials that can replace the } \\
\text { broken sturcture of bone tissue. One of the innovations conducted is the } \\
\text { characterization of sheep hydroxyapatite biocomposite. This study aims to } \\
\text { investigate the mechanical properties of the material Sheep } \\
\text { Hydroxyapatite (SHA) / shellac / wheat fluor. Sheep bone powder already } \\
\text { gained from the crusher process and meshing into size of } 100 \text { and are } \\
\text { soaked for } 24 \text { hours, then mixed with wheat flour with the ratio } 30: 70 \\
\% w t, 40: 60 \% \text { wt, } 50: 50 \% w t, 60: 40 \% \text { wt, } 70: 30 \% \text { wt. The next step } \\
\text { is the forming process and calcination at a temperature of } 900^{\circ} \mathrm{C} \text { with a } \\
\text { increase of } 10^{\circ} \mathrm{C} / \mathrm{min} \text {. Results of X-Ray Diffraction }(X R D) \text { shows that the } \\
\text { diffraction peak of SHA/shellac/wheat flour is the value of } 2 \theta: 32.0747^{\circ} \text {, } \\
33.1943^{\circ}, 32.5338^{\circ} \text {. The lowest hardness number of SHA/shellac/wheat } \\
\text { flour is } 2.86 \mathrm{VHN} \text { and the highest is } 14.80 \text { VHN, also the highest strong } \\
\text { pressure number is } 0.20 \mathrm{MPa} \text {. The result of microscophy at observation } \\
\text { using SEM shows Thar the SHA/shellac/wheat flour } 50: 50 \% \text { wt sample } \\
\text { has more porosity as. }\end{array}$ \\
\hline
\end{tabular}

\section{PENDAHULUAN}

Penggunaan biomaterial di bidang kesehatan khususnya orthopaedic terus meningkat seiring dengan bertambahnya berbagai cedera dan penyakit tulang [6]. Biomaterial merupakan penyusun utama komponen anorganik tulang. (Herdianto dkk, 2011). Salah satu unsur penyusun biomaterial yaitu hydroxyapatite. Hydroxyapatite (HA, $\left.\mathrm{Ca}_{10}\left(\mathrm{PO}_{4}\right)_{6}(\mathrm{OH})_{2}\right)$ adalah unsur anorganik alami dari tulang yang dapat dimanfaatkan untuk regenerasi tulang dan merekonstruksi jaringan tulang [5]. Biomaterial ini mempunyai struktur yang mirip dengan tulang manusia sehingga dapat digunakan sebagai pengganti tulang manusia yang rusak. Tulang asli yang direkonstruksi dengan hidroksiapatit akan cepat membangun ikatan dengan tulang asli dalam tubuh manusia. Pembuatan serbuk biokeramik hidroksiapatit menggunakan metode basah yang dibagi dalam tiga bagian yakni, metode pengendapan, metode panas hidro, dan metode hidrolisis [20]. Penelitian tentang hidroksiapatit (HA) dilapisi oleh lak berasal dari sekresi resin dari hewan serangga lac [12]. Berdasarkan hal tersebut diperlukan penelitian mengenai biokeramik tulang kambing dengan metode serbuk dengan pengikat shellac yang disintesiskan menggunakan terigu. Kemudian material diuji secara sintering dan diametral tensile strength (DTS) pada hydroxyapatite-zirconia composite. Sehingga hasil dari penelitian diharapkan dapat digunakan sebagai biomaterial dan bahan pengisian tulang (bone filler) untuk penderita patah tulang serta menjadi pengganti tulang yang rusak.

\section{METODOLOGI PENELITIAN}

Proses kalsinasi SHA/shellac/tepung terigu dilakukan dengan menggunakan furnace (brother XD $1700 \mathrm{M}$ ), proses kalsinasi dilakukan dari suhu $27^{\circ} \mathrm{C}$ (suhu kamar) hingga mencapai suhu $900^{\circ} \mathrm{C}$ dengan kenaikan suhu $10^{\circ} \mathrm{C} /$ menit kemudian ditahan selama 2 jam kemudian didinginkan pada temperatur ruangan. Selanjutnya, HA dicampur tepung dengan perbandingan berat $\mathrm{HA}$ dan berat tepung berturut-turut yaitu 70:30 60:40, dan 50:50. Sebuk yang sudah tercampur dikompaksi dengan beban 60 bar agar menjadi bentuk tablet dengan ukuran dameter $13 \mathrm{~mm}$ dan tebal $3 \mathrm{~mm}$. Spesimen tersebut kemudian dicelupkan kedalam larutan shellac dengan tujuan meningkatkan ikatan antar serbuk. Suhu kalsinasi 
Mekanika: majalah ilmiah mekanika 45 Volume 17 Nomor 2 September 2018

untuk mendapatkan sifat karakteristik spesimen BHA/Shellac/tepung yaitu $900^{\circ} \mathrm{C}$.

\section{HASIL DAN PEMBAHASAN} Analisa Fasa Hydroxyapatite dengan XRD (X-Ray Diffraction)

Pengamatan X-Ray Diffraction (XRD) material biokomposit SHA/shellac/tepung bertujuan mengindentifikasi fasa kristalin dalam material biokomposit dengan cara menentukan parameter struktur kisi untuk mendapatkan ukuran partikel. Pengamatan XRD ditunjukkan dengan $40 \mathrm{kV}, 30 \mathrm{~mA}$, dan $\mathrm{Cu} 1.54060 \mathrm{~A}$. Hasil pengamatan pola difraksi XRD diperoleh dari sampel SHA/shellac dan SHA/shellac/tepung setelah kalsinasi, seperti ditunjukkan pada gambar 1 berikut.

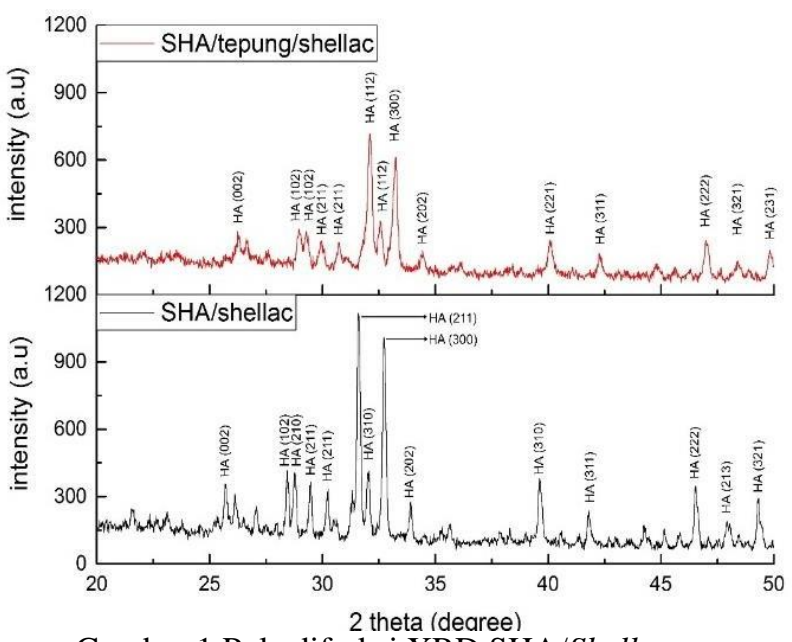

Gambar 1 Pola difraksi XRD SHA/Shellac

Gambar 1 menunjukkan bentuk pola difraksi XRD. Perbandingan pola difraksi antara SHA/shellac, SHA/shellac/tepung dan SHA yang memiliki nilai pola difraksi hampir sama, maka bisa dikatakan SHA/shellac dan SHA/shellac/tepung telah menjadi hidroksiapatit (HA). nilai $2 \theta: 31.760^{\circ}, 32.160^{\circ}$, $32.900^{\circ}$. Himpitan sudut HA sebagai konfirmasi derajat terbentuknya hidroksiapatit (HA) dari sampel uji SHA/shellac dan SHA/shellac/tepung.

\section{Analisa Uji Kekerasan Vickers (Vikkers Hardness Tester)}

Hasil uji kekerasan sampel tablet SHA/shellac/tepung 50:50, 60:40, 70:30, dan SHA/shellac (kontrol) [8]. Hasil pengujian kekerasan microvickers hardness tester pada spesimen sesudah kalsinasi $900^{\circ} \mathrm{C}$ selama 2 jam dengan kenaikan $10^{\circ} \mathrm{C} /$ menit didapatkan nilai kekerasan seperti terlihat pada Gambar 2 berikut. Pengujian kekerasan dengan microvickers diharapkan dapat mengetahui nilai kekerasan antara (SHA/shellac) dengan (SHA/shellac/tepung Terigu).

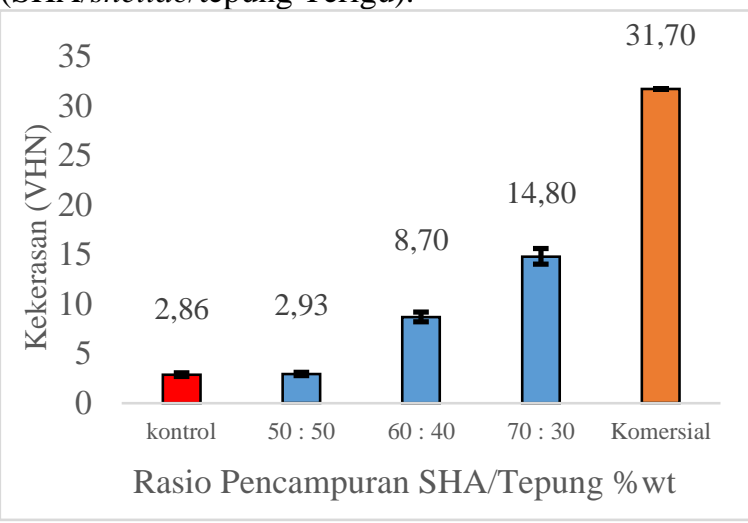

Gambar 2. Nilai kekerasan microvickers $\mathrm{BHA} /$ shellac/tepung setelah kalsinasi.

Gambar 2 menunjukkan bahwa nilai kekerasan sampel uji SHA/shellac (kontrol) memiliki nilai kekerasan yakni 2,86 $\pm 0,019$ VHN. Nilai kekerasan paling rendah dari sampel variasi campuran SHA/shellac/tepung terigu yakni variasi 50:50 \%wt dengan nilai kekerasan $2,93 \pm 0.15$ VHN. Terjadi peningkatan nilai VHN pada variasi 70:30 \%wt sekaligus menjadi nilai kekerasan tertinggi dari sampel SHA/shellac/tepung terigu dengan nilai kekerasan yakni 14,80 $\pm 0,79$ VHN. Nilai kekerasan komersial [9] sebesar $31,70 \pm 1,00$ VHN. Proses kalsinasi yang dilakukan pada suhu $900^{\circ} \mathrm{C}$ mengakibatkan menyusutnya kandungan tepung terigu dan menghilangnya zat organik seperti (kalsium, kadar air, lemak, dll) yang berada pada sampel uji. Menyusutnya kandungan tepung terigu, karena kandung tepung terigu seperti (karbohidrat, protein, kadar air, dll) menguap saat proses kalsinasi, hal tersebut menyebabkan kekerasan SHA dominan, sehingga sampel dengan kandungan SHA lebih banyak akan memiliki nilai kekerasan yang lebih tinggi dari sampel dengan kandungan SHA yang lebih sedikit. Hal ini diperkuat dengan hasil penelitian yang menyatakan bahwa semakin banyak \%wt bahan campuran pembentuk porus dapat menurunkan nilai kekerasan HA. Nilai kekerasan HA/YTZP pada penelitian yang dilakukan oleh [2] mengatakan bahwa, nilai kekerasan tertinggi yaitu 681.1 VHN (20\%wt YTZP), dan nilai kekerasan terendah yaitu $521 \mathrm{VHN}$ (60\% wt YTZP). [8] pada penelitiannya mengatakan bahwa nilai kekerasan pada suhu $1300^{\circ} \mathrm{C}$ yaitu 245.03 VHN dan nilai minimum yakni 137.24 VHN (suhu $1400^{\circ} \mathrm{C}$ ). Dari referensi diatas dapat disimpulkan bahwa pengaruh banyaknya bahan campuran pembentukan porus pada HA dan suhu mempengaruhi dari nilai kekerasan dari material HA. 
\begin{tabular}{c|c} 
Mekanika: majalah ilmiah mekanika & 46 \\
Volume 17 Nomor 2 September 2018 &
\end{tabular}

hasil kuat tekan terbaik yaitu $0.20 \mathrm{MPa}$. Hasil nilai HA komersil adalah 2.62 MPa lebih baik dari sampel variasi tersebut. Peningkatan nilai kuat tekan sampel SHA/shellac/tepung terigu terjadi akibat jumlah serbuk SHA yang semakin bertambah pada setiap variasi. Pada variasi 50:50\% wt sampel memiliki nilai kuat tekan terendah karena pada variasi ini pengikatan serbuk SHA oleh shellac terganggu oleh tepung terigu. Peristiwa tersebut berbanding terbalik pada variasi 70:30 \%wt yang memiliki nilai kuat tekan tertinggi karena pada variasi tersebut jumlah serbuk SHA yang lebih banyak dari tepung terigu membuat shellac mampu mengikat serbuk SHA secara sempurna.

Hal ini diperkuat dengan hasil Penelitian oleh [1] yang menyatakan bahwa nilai kuat tekan (DTS) HA pada temperatur $1000^{\circ} \mathrm{C}$ yakni $20.55 \pm 3.59$ MPa. Serupa dengan [1], [12] yang menyatakan bahwa penambahan shellac terhadap BHA dapat menaikkan nilai kuat tekan setelah kalsinasi pada suhu $1200^{\circ} \mathrm{C}$ selama 2 jam. Nilai kuat tekan optimum dari BHA/shellac yakni 5.2 MPa pada komposisi $10 \%$ penambahan shellac, untuk nilai kuat tekan minimum dari BHA/shellac yakni 3.2 MPa pada komposisi 2.5\% penambahan shellac.

\section{Scanning Electron Microschopy (SEM) Bovine} Hydroxyapatite (BHA)/shellac/tepung

Pengamatan SEM material biokomposit SHA/shellac/tepung terigu menggunakan SEM (VEGA3 TESCAM). Diharapkan hasil pengamatan menghasilkan bentuk porus pada SHA/shellac/Tepung Terigu setelah kalsinasi. SEM ditunjukkan dengan SEM HV $20.0 \mathrm{kV}$, LowVac $18 \mathrm{~Pa}, 16 \mathrm{~Pa}$, dan $16 \mathrm{~Pa}$. Pengamatan bentuk porus terhadap sampel tablet SHA/shellac/tepung terigu dilakukan dengan sampel tablet 50:50, 60:40, dan 70:30 \%wt. Berikut gambar 4 foto SEM sampel tablet SHA/shellac/tepung terigu.

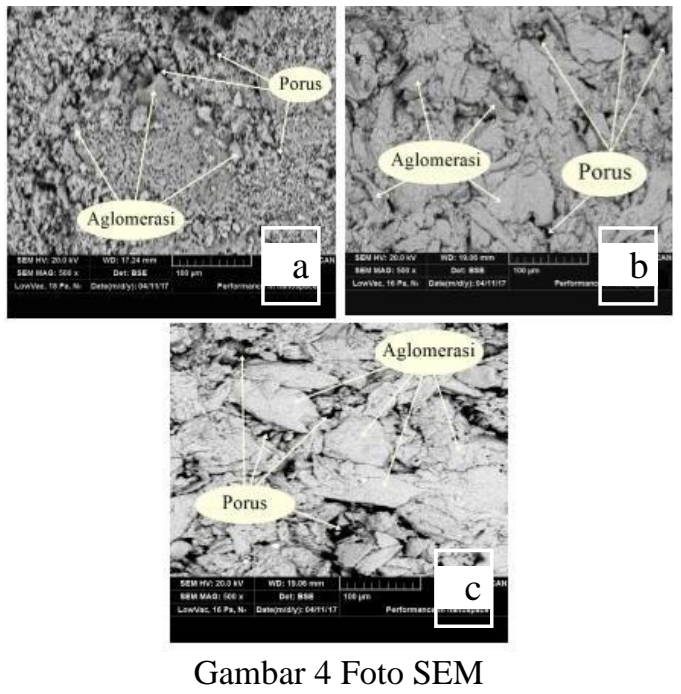


(a) BHA/shellac/tepung 50:50,

(b) BHA/shellac/tepung 60:40,

(c) BHA/shellac/tepung 70:30

Gambar 4 (a), (b), (c) menjelaskan tentang porus dan aglomerasi (gumpalan) yang terjadi pada sampel spesimen $\mathrm{SHA} /$ shellac/tepung terigu dengan perbandingan variasi 50:50, 60:40, 70:30 \%wt. Gumpalan HA terbentuk setelah proses kalsinasi. Terbentuk porus disebabkan oleh tepung terigu yang menyusut selama proses kalsinasi. Hal tersebut dikarenakan kandungan tepung terigu yang digunakan sebagai pembentuk porus memiliki titik lebur yang lebih rendah dari SHA. Kandungan tepung terigu seperti (karbonhidrat, Protein, kadar air,) memiliki titik lebur dibawah suhu $300^{\circ} \mathrm{C}$ dan SHA memiliki titik lebur $1670^{\circ} \mathrm{C}$, sehingga kandungan tepung terigu tersebut akan menguap ketika SHA/shellac/tepung terigu dikalsinasi pada suhu $900^{\circ} \mathrm{C}$. Pada Gambar 4.9 sampel perbandingan variasi 50:50 dapat dijelaskan bahwa gumpalan yang terjadi tidak beraturan, tidak merata dan porus tidak beraturan. Porus yang tidak beraturan menyebabkan melemahnya kekuatan material. Pada Gambar 4.b dan 4.c Gumpalan yang terjadi lebih padat dan porus yang terbentuk lebih merata sehingga hal ini dapat meningkatkan kekuatan material. Ukuran porus $\mathrm{SHA} /$ shellac/tepung terigu dari gambar 4.a, 4.b, dan 4c yakni $100 \mu \mathrm{m}$. Dari hasil yang ditunjukkan oleh gambar 4.a, 4.b, dan 4.c ini diperkuat dengan hasil penelitian yang menyatakan bahwa pada suhu yang lebih tinggi, partikel serbuk telah menyatu dan membentuk gumpalan HA yang lebih besar dan memiliki struktur mikro yang kasar [11], dan (Herliansya dkk, 2009) menyatakan bahwa terlihat banyaknya porus dimana terdiri dari butiran (intragranular pores). Proses porus diakibatkan adanya porositas tinggi sehingga terjadi mikrostruktur molekul pada serbuk SHA.

Dalam penelitian sheep hydroxyapatite (SHA/shellac/tepung terigu) dengan kalsinasi $900^{\circ} \mathrm{C}$ selama 2 jam dengan kenaikan $10^{\circ} \mathrm{C} /$ menit. Variasi perbandingan campuran yaitu 50:50, 60:40, 70:30 memiliki Pola difraksi XRD dengan intensitas 20: $32.0727^{\circ}, 33.1943^{\circ}, 32.5338^{\circ}$. Dari penelitian yang telah dilakukan menunjukkan adanya perubahan sifat meknik sampel. Perubahan nilai mekanik sampel SHA/shellac/tepung terigu terjadi seiring dengan penambahan tepung terigu sebagai pembentuk porus pada sampel. Nilai kekerasan dan nilai kuat tekan tertinggi terdapat pada sampel variasi pencampuran SHA/shellac/tepung terigu 70:30 \%wt dengan nilai $14.80 \pm 0.79 \mathrm{HVN}$ dan $0.20 \pm 0.015 \mathrm{MPa}$. Pencampuran SHA/shellac/tepung terigu pada sampel variasi 50:50 \%wt menyebabkan nilai kekerasan dan kuat tekan cenderung menurun hingga nilai terendah menjadi $2.93 \pm 0.15 \mathrm{HVN}$ dan $0.04 \pm 0.005 \mathrm{MPa}$. Berdasarkan pengamatan SEM yang dilakukan, dapat disimpulkan bahwa sampel SHA/shellac/tepung terigu memiliki pori interkoneksi sebesar $100 \mu \mathrm{m}$.

Akhirnya, variasi SHA/shellac/tepung terigu 70:30

$\%$ wt diidentifikasi menjadi variasi terbaik pada penelitian ini dengan nilai kekerasan $14.80 \pm 0.79$ HVN, kuat tekan sebesar $0.20 \pm 0.015 \mathrm{MPa}$, pada variasi SHA/shellac/tepung terigu 70:30 \%wt, pula menghasilkan pori interkoneksi sebesar $100 \mu \mathrm{m}$.

\section{KESIMPULAN}

Berdasarkan proses pengujian, pengamatan serta hasil pembahasan yang telah dilakukan dalam penelitian dapat diambil kesimpulan sebagai berikut:

1. Uji X-Ray Diffraction (XRD) menunjukkan SHA/shellac/tepung terigu memiliki unsur hydroxyapatite dengan ditunjukkannya puncak diffraksi SHA/shellac/tepung terigu dengan nilai 20: $32.0747^{\circ}, 33.1943^{\circ}$, $32.5338^{\circ}$. Nilai $2 \theta$ untuk senyawa HA sesuai dengan pola diffraksi standar.

2. Nilai kekerasan SHA/shellac/tepung terigu paling optimum yakni $14.80 \pm 0.79 \mathrm{HVN}$ (0.145 GPa). kemudian nilai kekerasan SHA/shellac/tepung terigu paling minimun yakni $2.93 \pm 0.15 \mathrm{HVN}(0.029 \mathrm{GPa})$.

3. Nilai kuat tekan $\mathrm{SHA} /$ shellac/tepung terigu paling optimum yakni $0.20 \pm 0.015 \mathrm{MPa}$, kemudian nilai kuat tekan $\mathrm{SHA} /$ shellac/tepung terigu paling minimum yakni $0.05 \pm 0.005 \mathrm{MPa}$.

4. Pengamatan SEM dilakukan terhadap sampel SHA/shellac/tepung terigu 50:50, 60:40, 70:30 \%wt. Pada sampel 50:50\%wt gumpalan HA tidak terbentuk secara merata dan porus yang terbentuk tidak beraturan. Pada suhu yang tinggi, partikel serbuk telah menyatu dan membentuk gumpalan HA yang lebih besar dan memiliki struktur mikroyang kasar. Porus HA terjadi karena menguapnya kandungan tepung terigu dan terurainya zat organik sehingga membentuk porus HA yang saling terkoneksi, rapuh dan mudah hancur.

\section{DAFTAR PUSTAKA}

[1] N. Akyurt, M. Yetmez, Karacayli, O. Gunduz, S. Agathopoulus, H. Gokce, M. L. Ovecoglu, dan F. N. Oktar, "A New Biomaterial : Sheep Dentine Derived Hydroxyapatite," Engineering Materials, Vol 493-492, Switzerland, 2012. 
Mekanika: majalah ilmiah mekanika 48 Volume 17 Nomor 2 September 2018

[2] Y. Chen, Z. Dong, and X. Miao, "The Effect of Yitria-Stabillized Zirconian on The Properties of the Flourine-Substituted Hydroxyapatite Ceramics Prepared by Pressureless," J. of Biomimetics, Biomaterial and Tissue Eng., Vol.1, pp. 57-58, 2008.

[3] N. Demirkol, F. Oktar, F. S. Kayali, "Mechanical and Microstructural Properties of Sheep Hydroxyapatit (SHA)-Niobium Oxide Composite.," Proseedings of the Int. Congress on Advances in Applied Physics and Mater. Sci., Antalya 2011, 2012.

[4] N. Demirkol, F. Oktar, F. S. Kayali, "Influence of Nobium Oxide on the Mechanical Properties of Hydroxyapatite," Key Engineering Materials, vol. 529-530, pp. 29-30, Switzerland, 2013.

[5] M. Fitriawan, S. R. Amalia, B. A. Saputra, E. Setyawati, A. Yulianto, dan P. M. Aji, "Sintesis Hidroksiapatit Bahan dasar Tulang Sapi dengan Metode Pretipitasi sebagai Kandidat Pengganti Graft Berdasarkan Compressive Strengh," Prosiding SNMF 2014, Semarang, 2014.

[6] Gunawarman, A. Malik, "Karakteristik Fisik dan Mekanik Tulang Sapi Variasi Berat Hidup Sebagai Referensi Desain Material Implan," Seminar Nasional Tahunan Teknik Mesin (SNTTM) ke-9, Palembang, 2010.

[7] N. Herdianto, "Studi Bioresorbabilitas Biokeramik Biphasic Calcium Phospate (BCP) Sebagai Material Pengganti Tulang," Tesis, Universitas Indonesia, Salemba, 2011.
[8] M. K. Herliansyah, D. A. Nasution, M. Hamdi, A. Ide-Ektessabi, M. W. Wildan, A. E. Tontowi, "Preparation and Characterization of Natural Hydroxyapatite : A Comparative Study of Bovine Bone Hydroxyapatite from Calcite," Material Science Forum, vol. 561565, Switzerland, 2007.

[9] M. K. Herliansyah, M. Hamdi, A. IdeEktessabi, M. W. Wildan, dan J. A. Toque, "The Influence of Sintering Temperature on The Properties of Compacted Bovine Hydroxyapatite," Material Science and Engineering, C vol. 29, pp. 1674-1680, 2009.

[10] Majelis Ulama Indonesia., Fatwa., "Penggunaan Shellac sebagai bahan pangan, obat-obatan dan kosmetika," No. 27, 2013.

[11] I. Sopyan, J. Kaur, "Preparation and Characterization of Pourous Hydroxyapatite through Polymeric Sponge Method," Ceramics International, vol. 35, pp. 31613168, Malaysia, 2009.

[12] Y. C. The, C. Y. Tan, S. Ramesh, J. Purbolaksono, Y. M. Tan, H. Chandran, W. D. Teng dan B. K. Yap "Effect of Calcination on the Sintering Behavior of Hydroxyapatite," Faculty of Enginering, University of Malaya, 50603, Kualalumpur, Malaysia, 2014.

[13] J. Triyono, S. Susmartini, Susilowati., S. A. Murdiyantara, "Shellac Coated Hydroxyapatite (HA) Scaffold for Increasing Compression Strength," Advanced Material Researcg, vol. 1123, pp. 378-382, 2015. 